\title{
Gopboa 3a
}

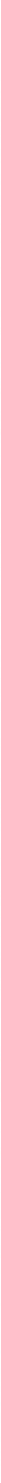

Толедо. Худ. Генаро Перез Виллаамил, 1836 г.

Музей изобразительных искусств Бильбао, Испания. 


\section{kacrinusbckoe

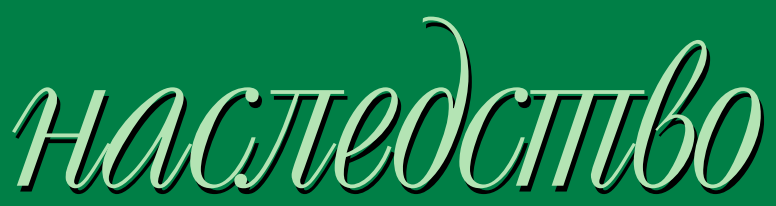

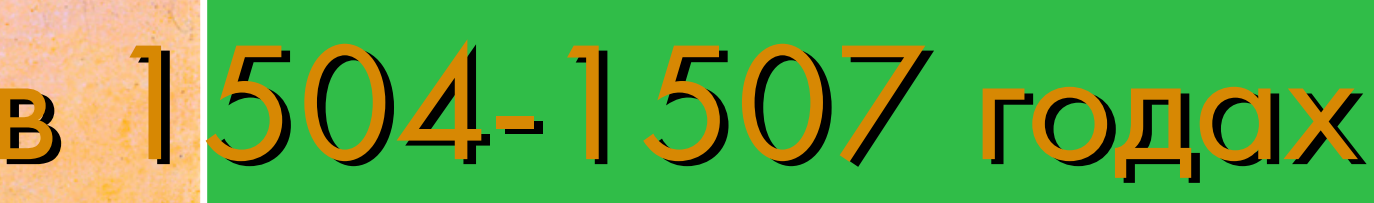

Дмитрий Боровков,

историк-архивист
В XV веке, в результате сближения королевств Кастилия и Арагон на Пиренейском полуострове сложились предпосылки к заключению политического союза между их правителями, принадлежащими к одной династии - дому Трастамара. Претворение их в реальность заняло более десяти лет, начиная с того момента как в 1469 году наследник арагонского престола Фердинанд женился на своей троюродной сестpe, кастильской принцессе Изабелле, став ее соправителем после вос- шествия на престол в 1474 году. Тем не менее, в восприятии кастильской знати муж королевы, унаследовавший в 1479 году арагонскую корону, продолжал быть иностранцем, что стало особенно заметно после того, как на политической повестке дня оказался вопрос о наследовании кастильской короны. Первоначально как Кастилию, так и Арагон должен был наследовать сын Фердинанда и Изабеллы инфант Хуан; после его смерти в 1497 году это право перешло к его сестре Изабелле, а затем

Первоначально как Кастилию, так и Арагон должен был наследовать сын Фердинанда и Изабеллы инфант Хуан; после его смерти в 1497 г. это право перешло к его сестре Изабелле, а затем к ее сыну от португальского короля Мануэла I Мигелю, который также скоропостижно скончался. Так наследницей стала вторая дочь Фердинанда и Изабеллы Хуана. 


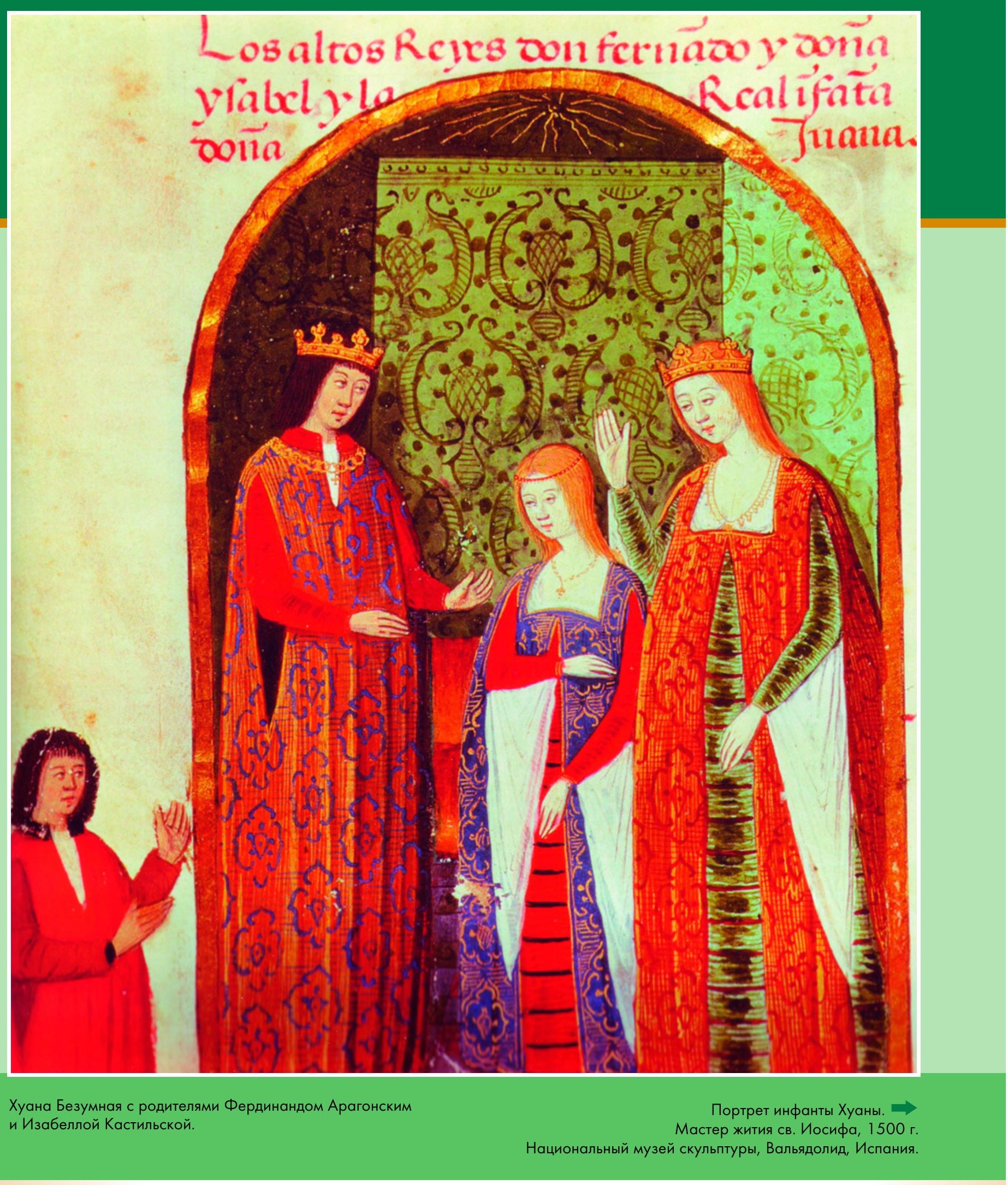

к ее сыну от португальского короля Мануэла I Мигелю, который также скоропостижно скончался. Так наследницей стала вторая дочь Фердинанда и Изабеллы Хуана. В 1496 году, в семнадцать лет, она была выдана замуж за бургундского герцога Филиппа Габсбурга, сына германского короля Максимилиана I.

Хуана и Филипп в первый раз отправились в Испанию в конце 1501 года и прибыли на Пиреней- ский полуостров через территорию Франции. Присяга на верность Хуане и ее мужу была принесена 22 мая в Толедо, где были созваны сословные представительства (кортесы) Кастилии и Леона, и 27 октября 


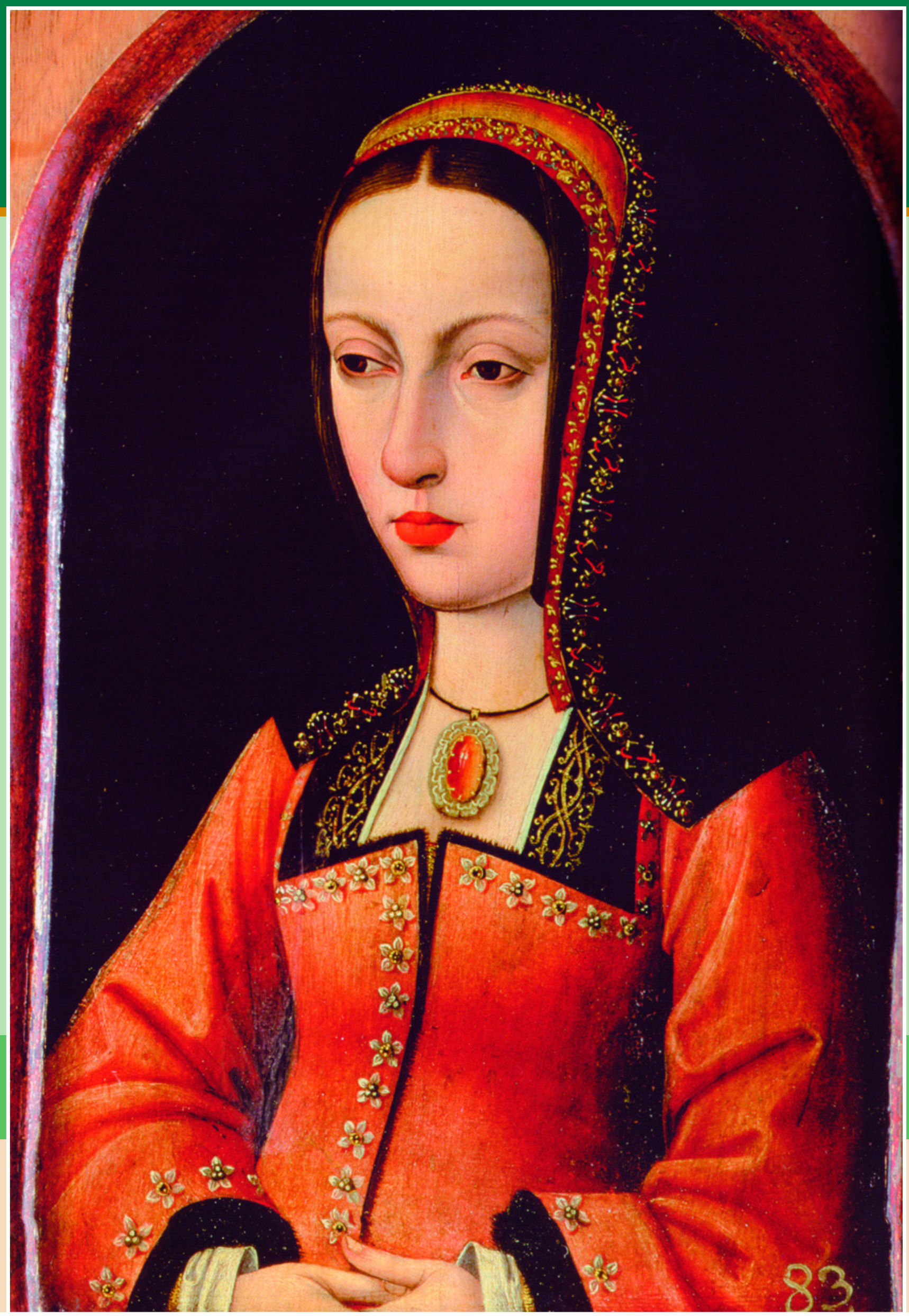




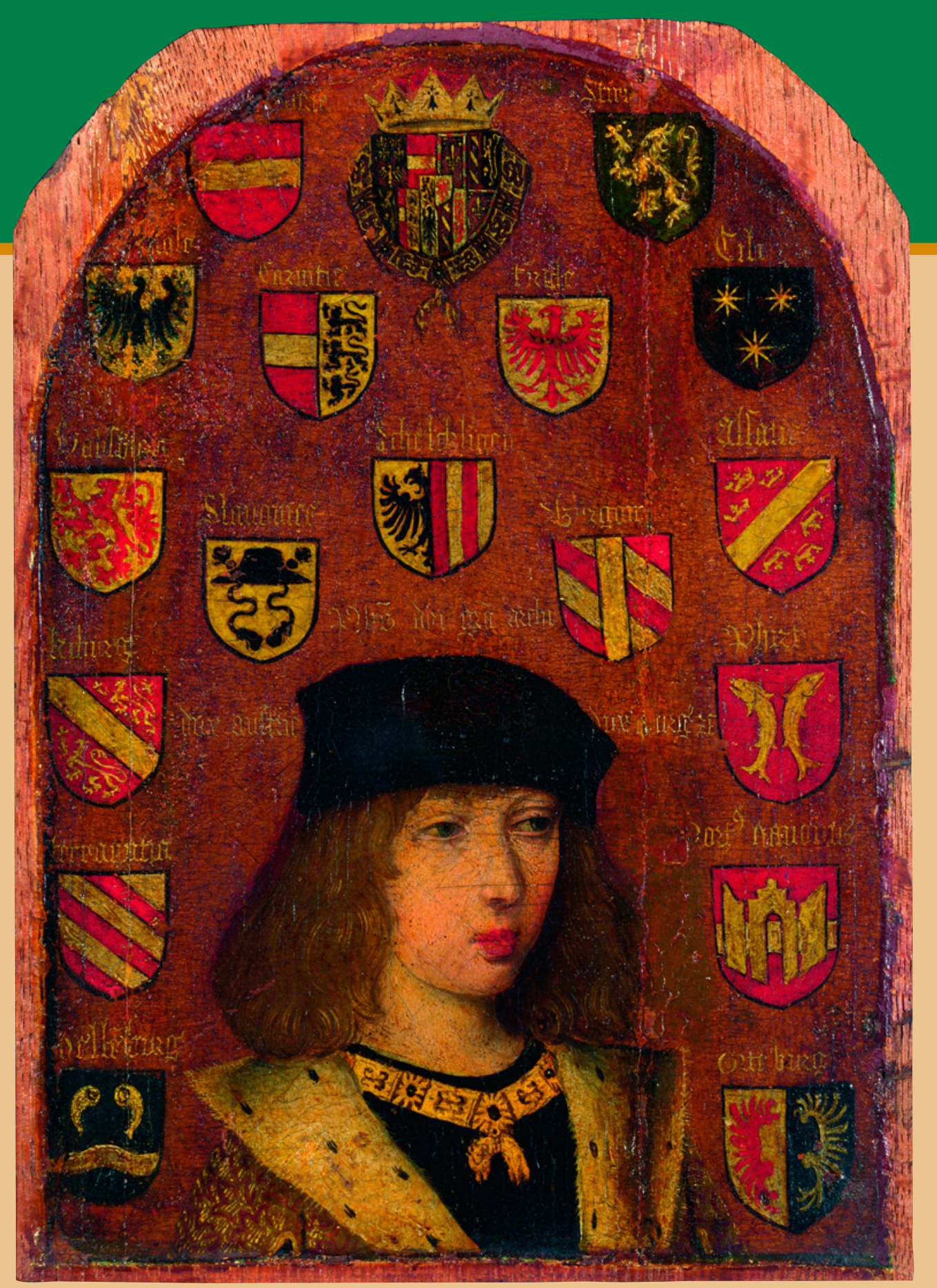

Филипп Красивый. Худ. Питер ван Конинкслоо. 1493-1493 гг. Национальная галерея, Лондон.

Император Максимилиан I Габсбург и Мария Бургундская с детьми, $\Rightarrow$ старший (стоит с рядом с матерью) - Филипп I Красивый. Худ. Бернхард Штригель. 1515 г. Музей истории искусств, Вена.

в Сарагосе, где собрались кортесы Арагона, Каталонии и Валенсии. Вскоре после этого произошло обострение франко-испанских отношений из-за разногласий по поводу оккупации Неаполитанского королевства, территория которого была разделена между двумя государствами.
Хуана, которая должна была родить, осталась в Испании, а Филипп в начале 1503 года отправился назад, так же через территорию Франции. Однако его посредничество в урегулировании конфликта в Неаполе окончилось неудачей - король Людовик XII «не захотел придти к какому-либо соглаше-
CLEOPHIS FR SEPHI : MARITI

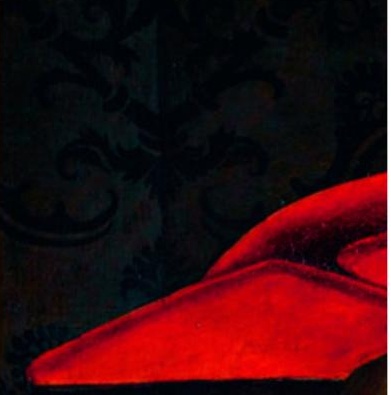


ATER CARNALIS I0= DIVAE VIRG MIARIE

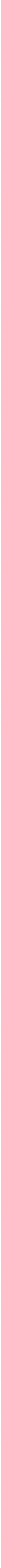




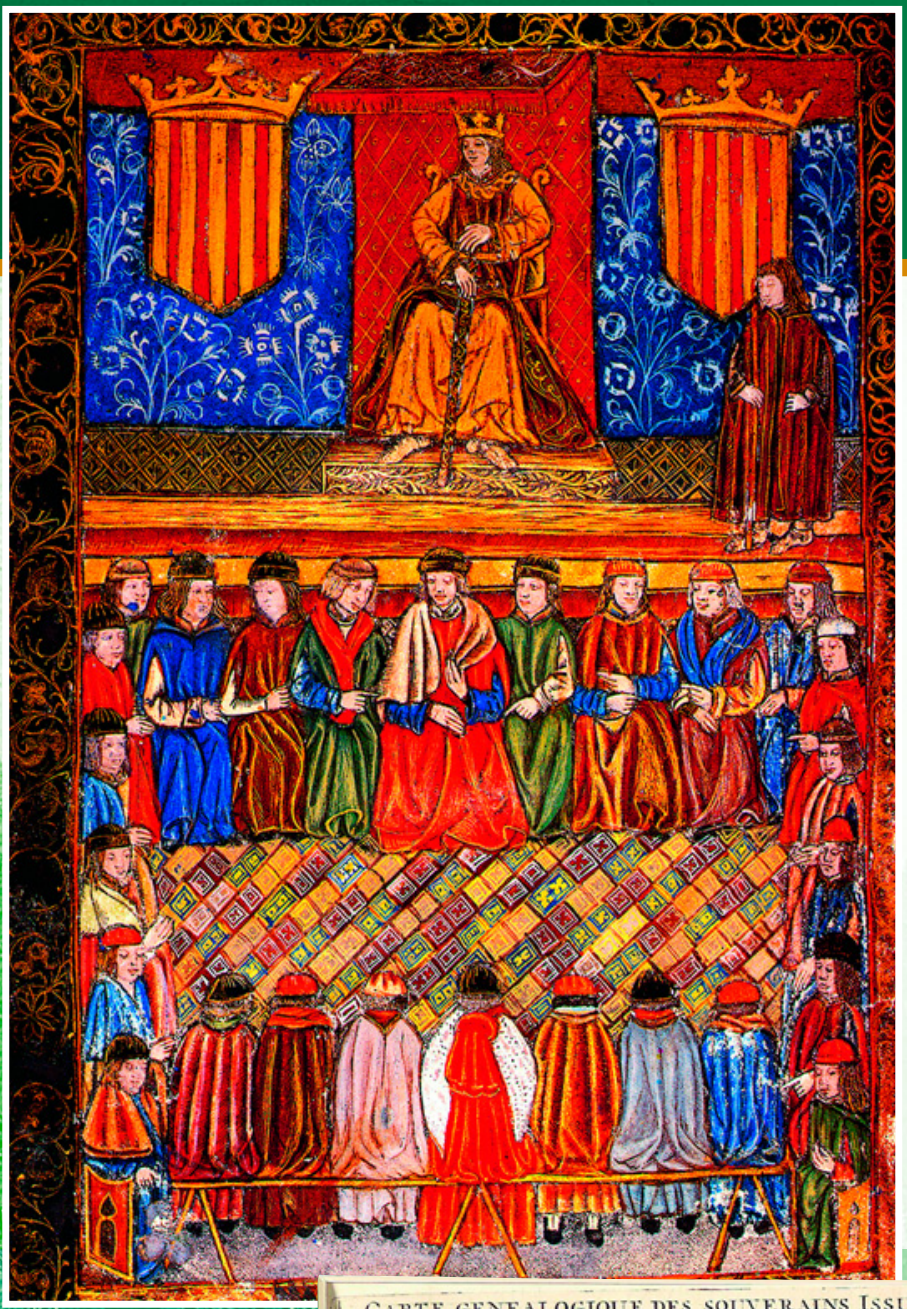

nat.

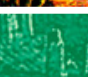

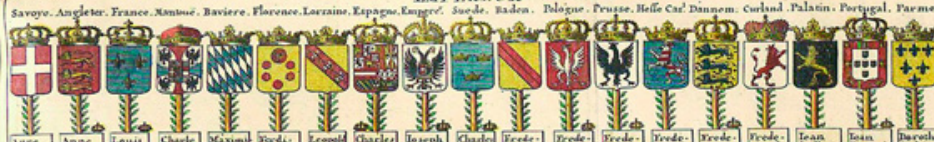
*

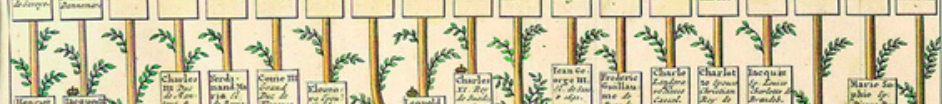
3(4) m. (c) ise
Фердинанд II Арагонский на собрании

каталонских кортесов. Миниатюра XV в.

нию по просьбе принща Филиппа» - пишет хронист XV-XVI веков Лоренсо Падилья. Кроме того, принц так сильно заболел в Лионе, что на протяжении почти двух месяцев находился между жизнью и смертью.

Хуана, ставшая тем временем матерью (у нее родился сын Фердинанд), в Нидерланды отправилась лишь весной 1504 года. Отношения между супругами ухудшались из-за того, что Филипп пользовался успехом у женщин - он и в историю вошел как - Филипп Красивый. РевниХуна пыталась сопротивляться измевозможности выполнять королевские функ- 
Внизу:

Генеалогическое древо европейских правящих домов.

Галерея аукционного дома Dorotheum.

ции, «руководить и править» В «этих королевствах и сенъориях надлежало ее отцу Фердинанду. Такое положение дел должно было сохраняться до 20-летия старшего сына Филиппа и Хуаны Карла.

Кончина Изабеллы в ноябре 1504 года открыла путь спорам о регентстве. Неоднократно редактировавшееся завещание королевы, с одной стороны, предусматривало, что подданным надлежит выказывать «всю полноту верности, преданности, повиновения, почтения и вассальных служб» не только Хуане, но и «светлейшему $и$ дражайшему приниу дону Филиппу», как ее супругу. С другой стороны, принцессе и принцу надлежало «всегда повиноваться и быть по-

Отношения между супругами ухудшались из-за того, что Филипп пользовался успехом у женщин - он и в историю вошел как Philippe Le Beau - Филипп Красивый. Ревнивая Хуана пыталась сопротивляться изменам мужа и однажды приказала остричь волосы одной из его фавориток. В конце концов, Филипп стал сомневаться в адекватности супруги, о чем проинформировал ее родителей.

корными» по отношению к королю Фердинанду, «не выходить из повиновения его распоряжениям, обращаться с ним и чтить его с подобаюшим повиновением и уважением, оказывать и заставлять оказывать ему все почести, которые обязаны оказывать хорошие дети своему отиу, и следовать его распоряжениям и советам».
Разумеется, столь противоречивая воля могла иметь различные толкования, что не замедлило сказаться на отношениях Фердинанда и Филиппа. В послании, направленном 26 ноября членам королевской Аудиенции и Канцелярии в Вальядолиде, Фердинанд отмечал, что «светлейшая королева» в своем завещании «оставила

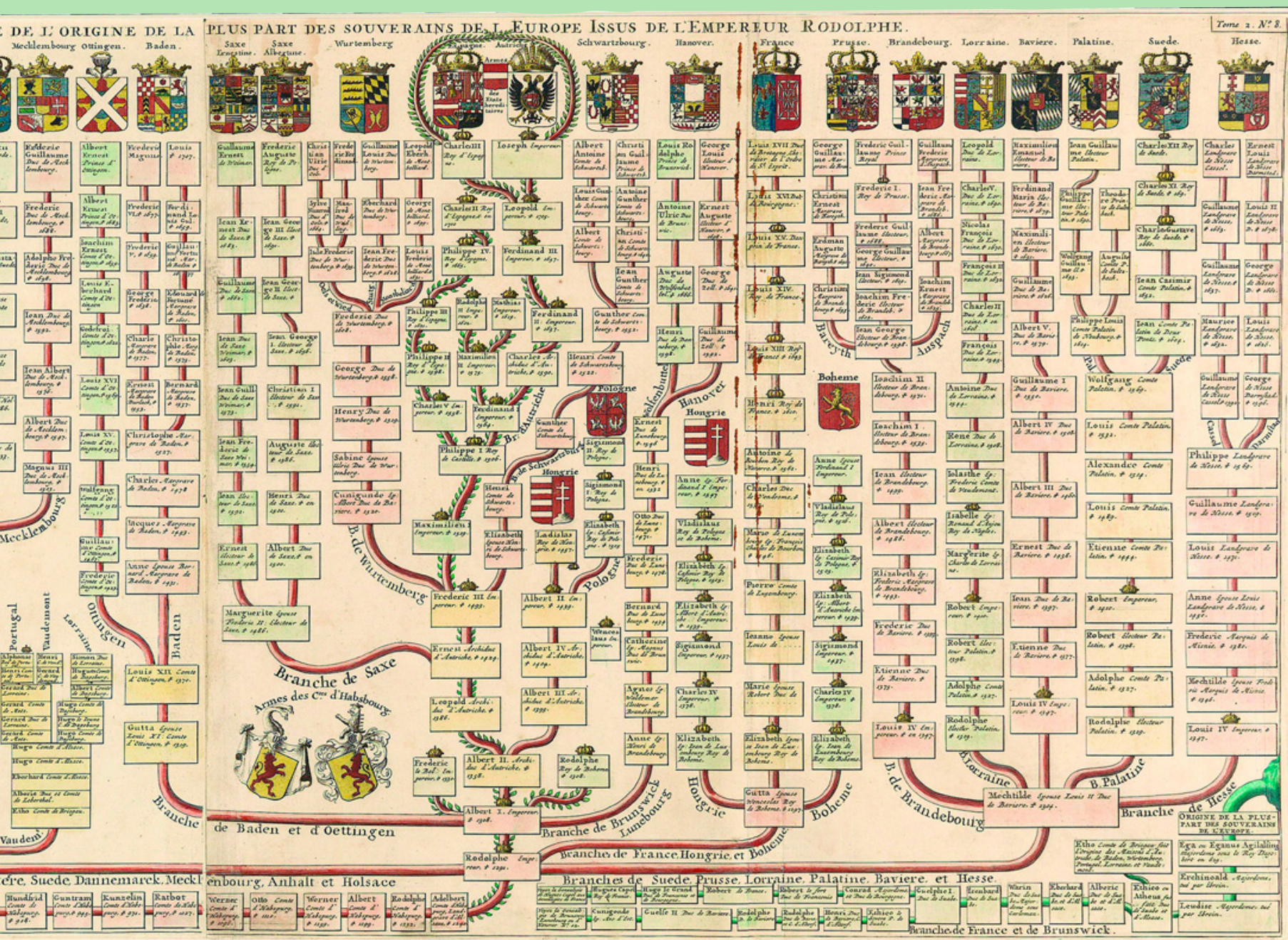




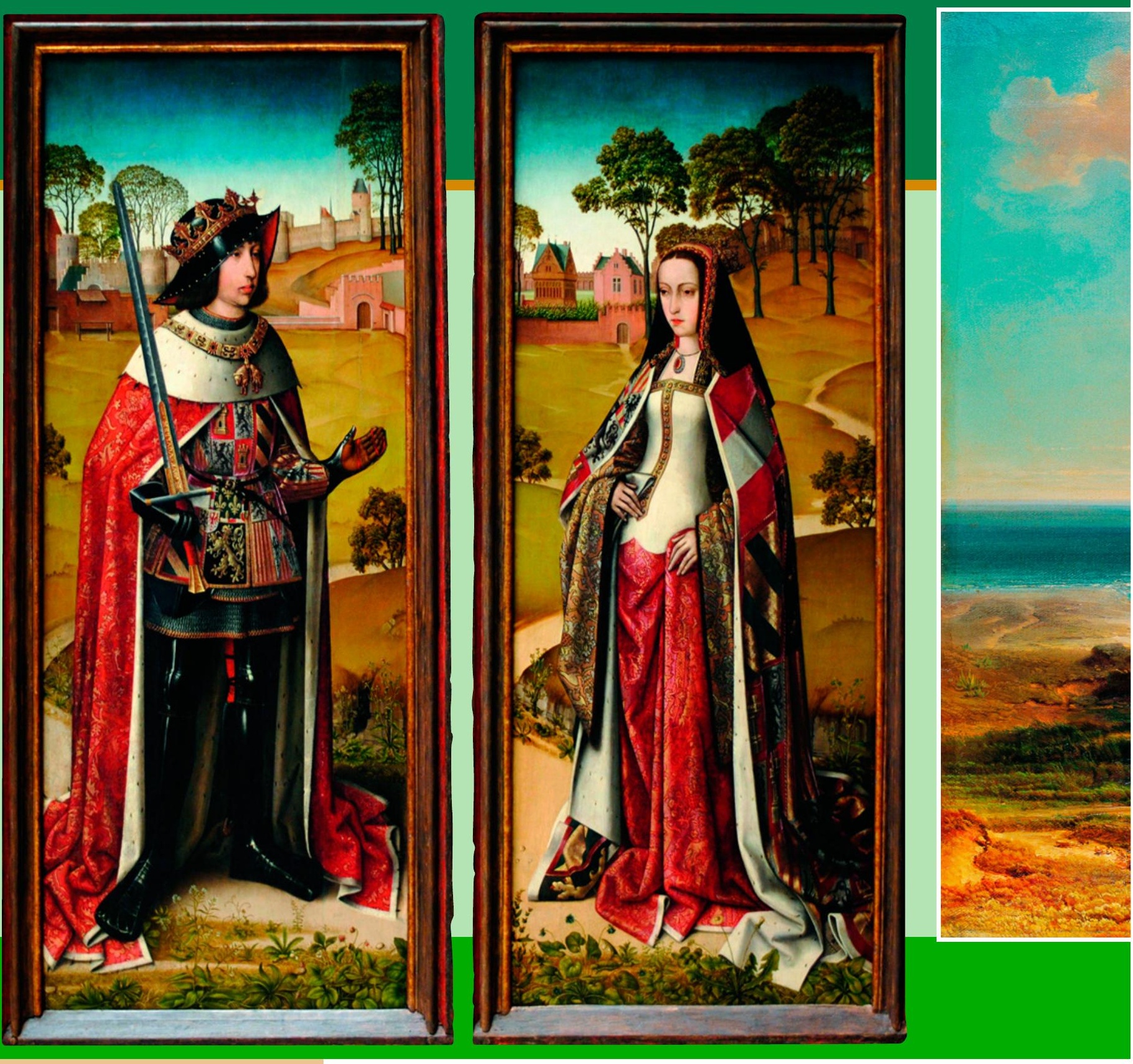

Филипп Красивый и Хуана Безумная. Ставни триптиха.

Мастер жития св. Иосифа, 1500 г. Королевские музеи изящных искусств, Брюссель.

распоряжение, по которому я должен был бы держать администрацию и управление королевствами и сеньориями Кастилии, Леона и Гранады за светлейшую королеву донъю Хуану, нашу весьма дорогую илюбимую дочъ».

Филипп, который узнал о смерти королевы из послания Фердинанда, в ответном письме написал: «мы немедленно посылаем $\kappa$ Вашему Величеству мессира де Вейрэ, который предоставит удовлетворение во всем, и ми надеемся, доставив удовольствие Господу, без промедления отправиться в путь для того, чтобы увидеть Ваше Высочество и служить всеми нашими силами, как добрые и послушные дети». Однако, Фердинанд, по всей видимости, был не в восторге от намерений зятя, которые грозили обернуться для него большими проблемами после того, как в начале 1505 года на кортесах в Торо королевский титул перешел к Хуане, несмотря на сомнения в ее адекватности. Там же было принято решение о назначении Фердинанда «законным опекуном, администратором u правителем сеньорий и королевств» в соответствии с последней волей королевы Изабеллы.

Прибыв в Испанию, граф де Вейрэ вошел в контакт с представителями оппозиции и начал вербовать сторонников среди кастильской элиты, в числе которых оказались герцоги Нахера, Инфантадо и Медина-Сидония, маркизы Виллена и Плиего, граф Бенавенте и некоторые другие феодалы. Хронист XVI века Андрес Бернальдес сообщает следующее: 


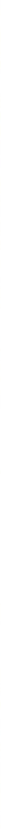

Пиренейское побережье Коста де Ла Лус с видом на Гибралтар. Худ. Фриц Бамбергер. 1855 г. Музей Кармен Тиссен, Малага, Испания.

когда «король дон Фердинанд управлял Кастилией за свою дочь донъю Хуану и за короля дона Филиппа, в некоторых кастильских рыщарях возникла ревность и зависть, и они стали добиваться прибытия короля дона Филиппа, и по счастью, он не смог отправиться так быстро из Фландрии, чтобы приити иарствовать, хотя и оттуда он мог править и приказывать в Кастилии, если бы к этому не побуждали и не призывали некоторые гранды Кастилии, сеявиие раздоры и устраивавшие разногласия между ним и королем доном Фердинандом, его тестем, по той причине, что дон
Филипп находился во многих делах, потому что славной памяти королева донья Изабелла приказала и распорядилась в своем завешании.
Несколько иначе представляют ситуацию более поздние авторы. Педро Мехиа (1497-1551 гг.) пишет, что Филипп отправил к Фердинанду

\section{Прибыв в Испанию, граф де Вейрэ вошел}

в контакт с представителями оппозиции и начал вербовать сторонников среди кастильской элиты, в числе которых оказались герцоги Нахера, Инфантадо и МединаСидония, маркизы Виллена и Плиего, граф Бенавенте и некоторые другие феодалы. 
Хуана Безумная с сыном Карлом. Худ. Франц Вольфганг Рорич. ХІХ в.

своих послов, чтобы потребовать его отъезда в Арагон, однако Фердинанд отказался это сделать, мотивируя свое решение необходимостью оказывать помощь в управлении. Более подробно рассказывает Алонсо де Санта-Крус (1505-1567 гг.), сообщающий, что Филипп «решил написать писъио королю дону Фердинанду, очень прося его уехать в свои арагонские королевства, оставив свободными королевства Кастилию и Леон, так как они принадлежали донъе Хуане, его жене. Король дон Фердинанд в своем письме ответил, говоря о тол, что в то время как он вступил в королевства Кастилии, для того, чтобы править, они были возмущенными и полными сильных волнений, раздоров и беспорядков, и многие города и селения были захвачены у кастильской короны изза нужды и плохого управления, которое осуществлял король дон Энрике, его предшественник, и все это, что он приобрел и достиг со своей супругой, католической королевой, вернув королевство в состояние полного мира и спокойствия, находится в этол состоянии до настоящего момента, благодаря хорошему его управлению; он должен видеть, что молод и мало подготовлен для управления этими королев-

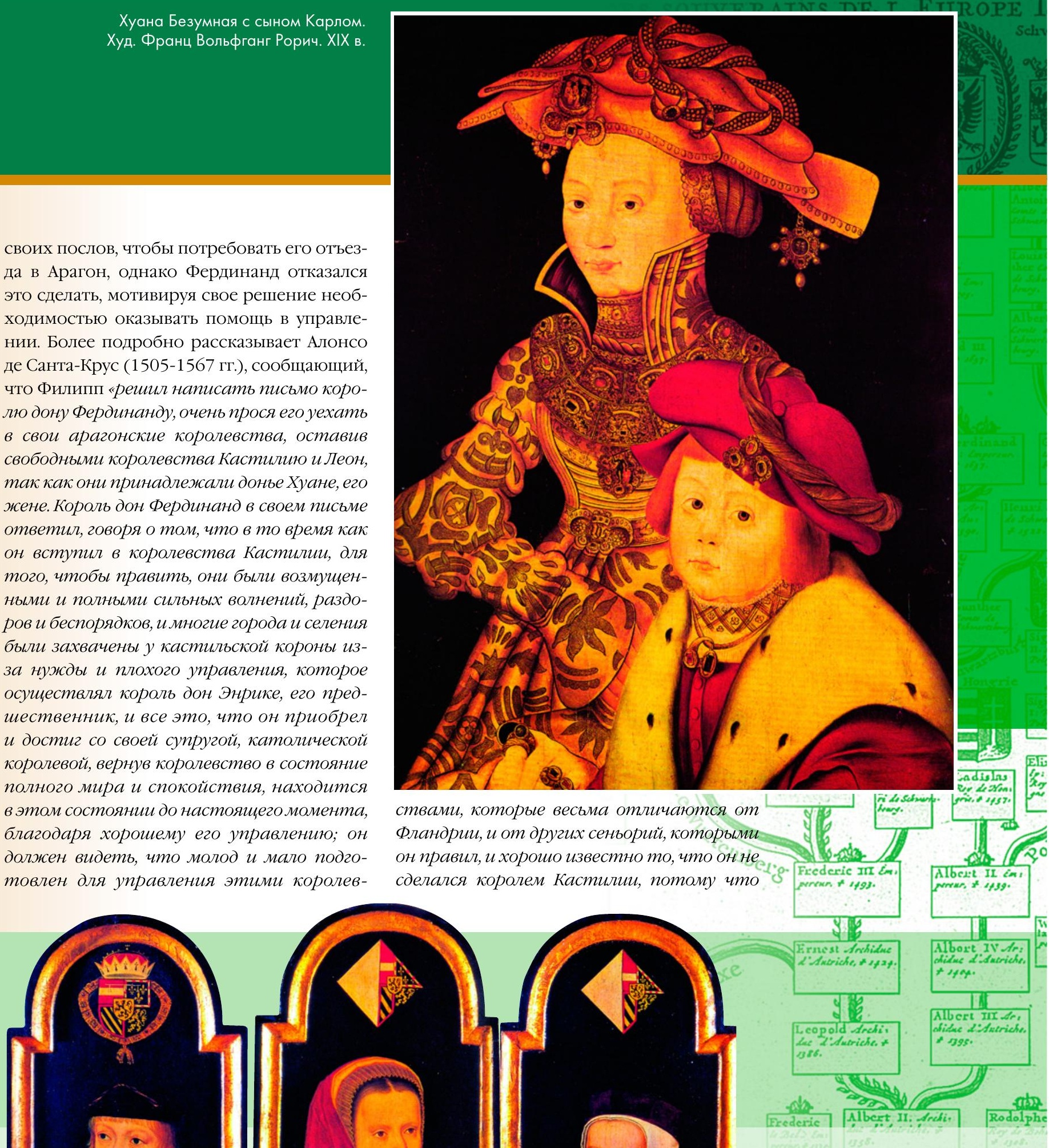

Дети Филиппа Красивого и Хуаны Безумной:

сын Карл, впоследствии император Священной Римской империи Карл V и дочери Элеонора Австрийская и Изабелла Австрийская.

Музей истории искусств, Вена, Австрия. 


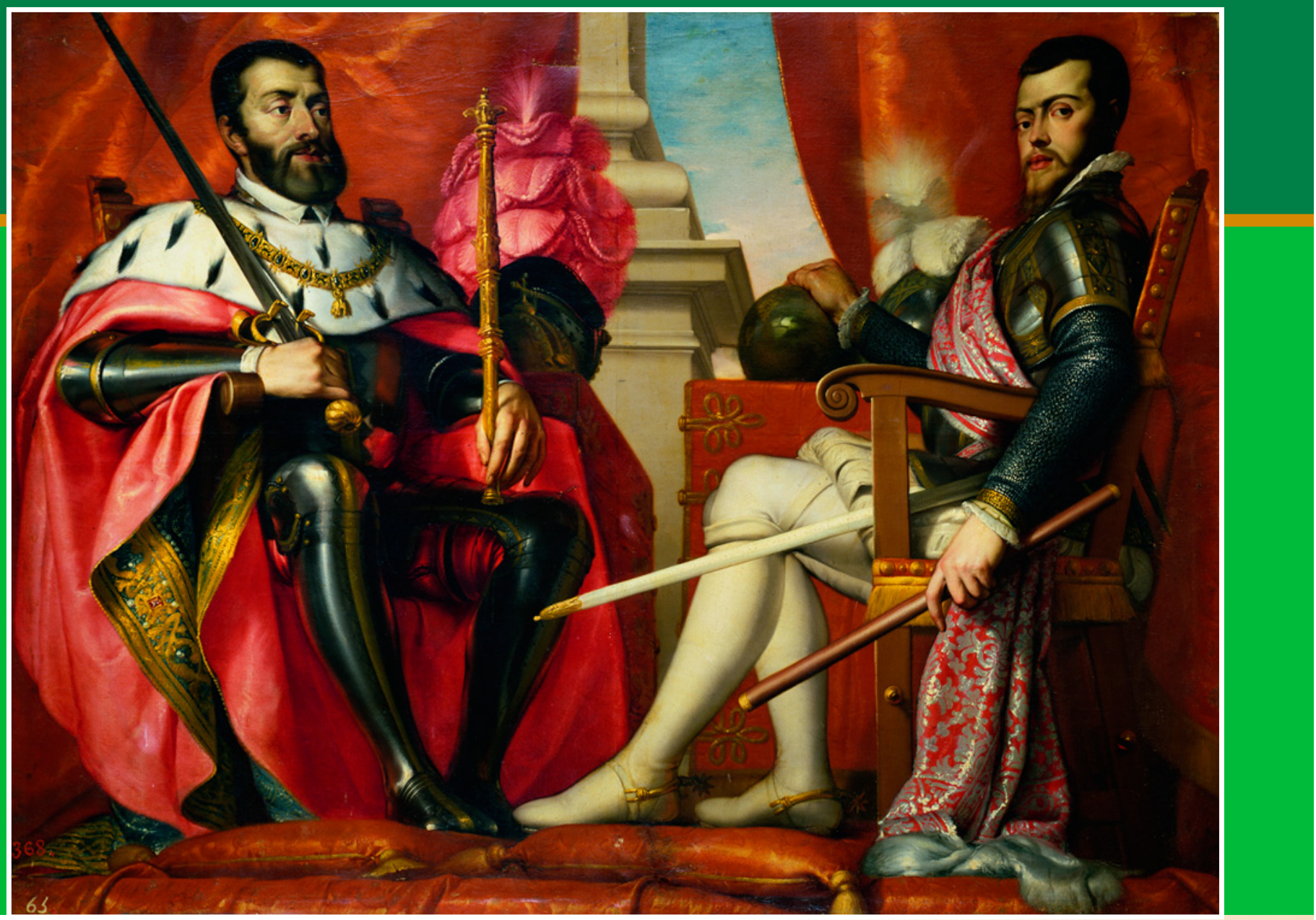

титул короля по своей собственной воле он сложил с себя, дав его своей дочери, донъе Хуане, но не хотел, чтобы в иных делах Кастилия оставалась без правителя».

В то же время Фердинанд пытался оказывать давление на свою дочь, чтобы она отказалась приезжать в Испанию. Для переговоров с зятем он отправил во Фландрию официальную делегацию во главе с епископом Кордовы Хуаном де Фонсекой, а неофициальную миссию поручил Лопе Кончильосу, который был секретарем Филиппа во время его пребывания в Испании. Как пишет Лоренсо Падилья, Кончильос и епископ Фонсека «тайно $u$ открыто мешали всему, чему могли, чтобы король и королева не прибыли в Испанию", но узнав, что воля короля "состояла в том, чтобы ехать этот епископ, Кончильос и Гутьерре Гомес де Фуэнсалида, который был послом короля дона Фердинанда, зная, что королева испытывает больиую любовь $к$ своему отиу, тайно договорились с ней о передаче власти королю, ее отму, для того, чтобы он управлял Кастилией во все дни своей жизни». Санта Крус добавляет, что Фердинанд написал своей дочери письмо, которое было передано ей Кончильосом. После прочтения письма Хуана неохотно согласилась позволить отцу остаться в Кастилии, однако, сохра-
Император Священной Римской империи Карл У с сыном и наследником

Филиппом II королем Испании, Португалии и Алгарве Худ. Антонио Ариас Фернандес. XVII в. Музей Прадо, Мадрид

После того, как документ был составлен, королевский секретарь Мигель Ферреро показал его Филиппу, который, узнав о том, какая миссия была поручена Кончильосу, приказал схватить его, а Хуану лишил тех слуг, которые были предоставлены ей родителями, чтобы пресечь ее контакты с родиной. Кончильос был заключен в тюрьму, подвергнут пыткам и долго находился в беспамятстве, прежде чем стало известно, что за ним стояли Фонсека и Фуэнсалида. 


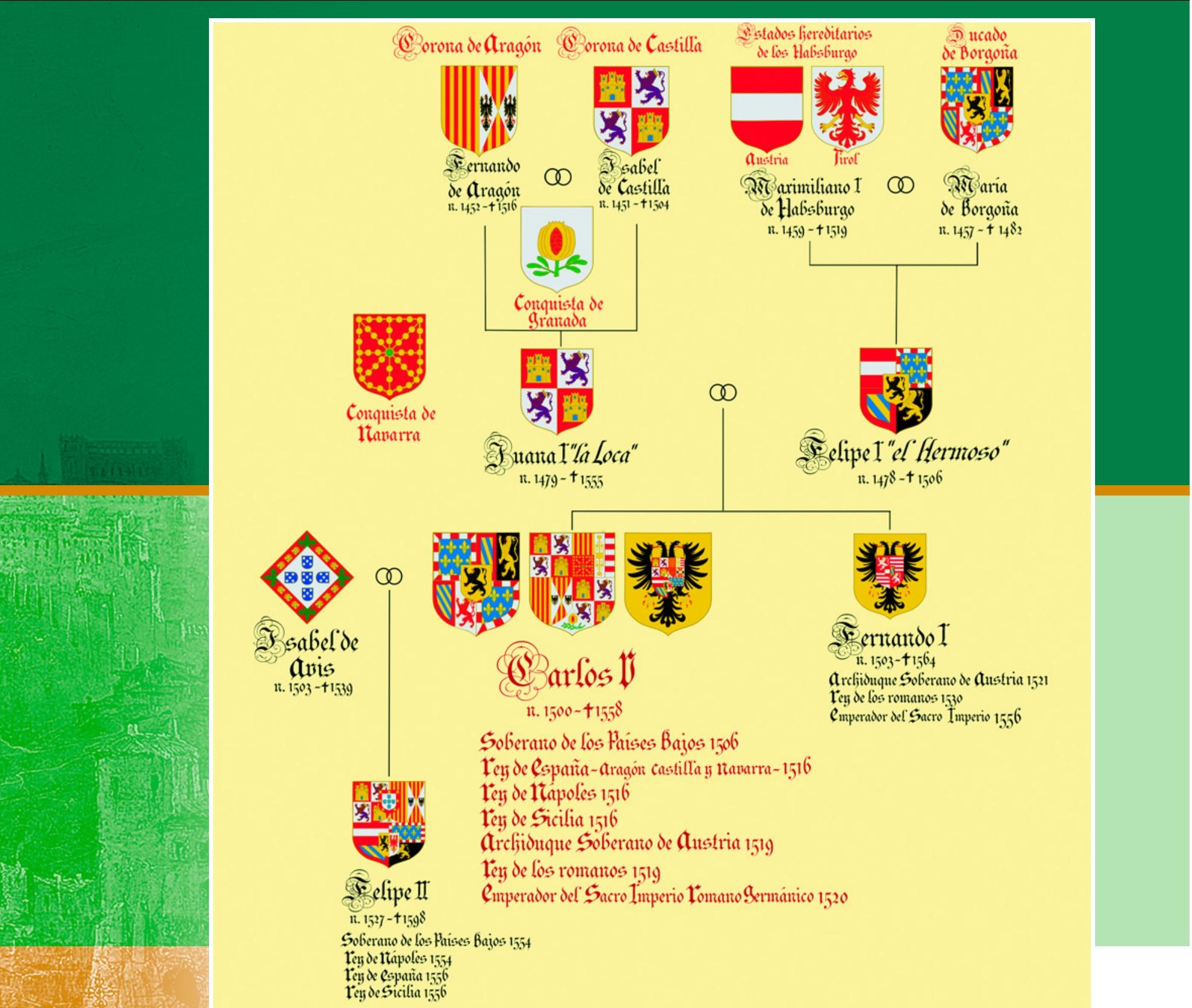

нить в тайне это решение не удалось. После того, как документ был составлен, королевский секретарь Мигель Ферреро показал его Филиппу, который, узнав о том, какая миссия была поручена Кончильосу, приказал схватить его, а Хуану лишил тех слуг, которые были предоставлены ей родителями, чтобы пресечь ее контакты с родиной. Кончильос был заключен в тюрьму, подвергнут пыткам и долго находился в беспамятстве, прежде чем стало известно, что за ним стояли Фонсека и Фуэнсалида. Таким образом, воспрепятствовать прибытию Филиппа в Испанию оказалось невозможно.

24 ноября 1505 года Фердинанду удалось заключить в Саламанке соглашение с графом де Вейрэ, определявшее порядок урегулирования разногласий с Филиппом, который задержался в Нидерландах из-за войны с герцогом Карлом Гельдернским. Несмотря на то, что в документе декларировались цель и желание обеих сторон «быть сейчас и в будущем всегда едиными и весьма согласными в том, что есть право", это «единение и согласие» продлилось всего несколько месяцев.

Во второй раз Филипп и Хуана отправились в Испанию морем 10 января 1506 года, посетив тогда же Англию, где были приняты королем Генрихом VII. В конце апреля 1506 года они прибыли в Испанию и высадились в Ла-Корунье. Ко двору новых монархов стали стекаться представители аристократии. Позиции Филиппа укреплялись, поэтому он выжидал время и отказывался вступить в переговоры с Фердинандом, 
$<$ Гербы королей Испании, в правление которых страна достигла пика своего могущества. Под контролем зародившейся одновременно с Великими географическими открытиями, испанской империи, помимо испанской части Пиренейского полуострова находились обширные земли в Америке, Ост-Индии; в Европе под их властью находились Испанские Нидерланды, большая территория современной Италии и другие территории: Мальта на Средиземном море, анклавы в Северной Африке: Сеута и Оран. В период 1580-1640 годов согласно Иберийской унии, Испания владела Португалией и всей ее обширной колониальной империей.
Изображение Европы в виде королевы, на короне которой написано «Испания».

Гравюра из «Космографии» средневекового немецкого ученого Себастьяна Мюнстера. 1588 г.

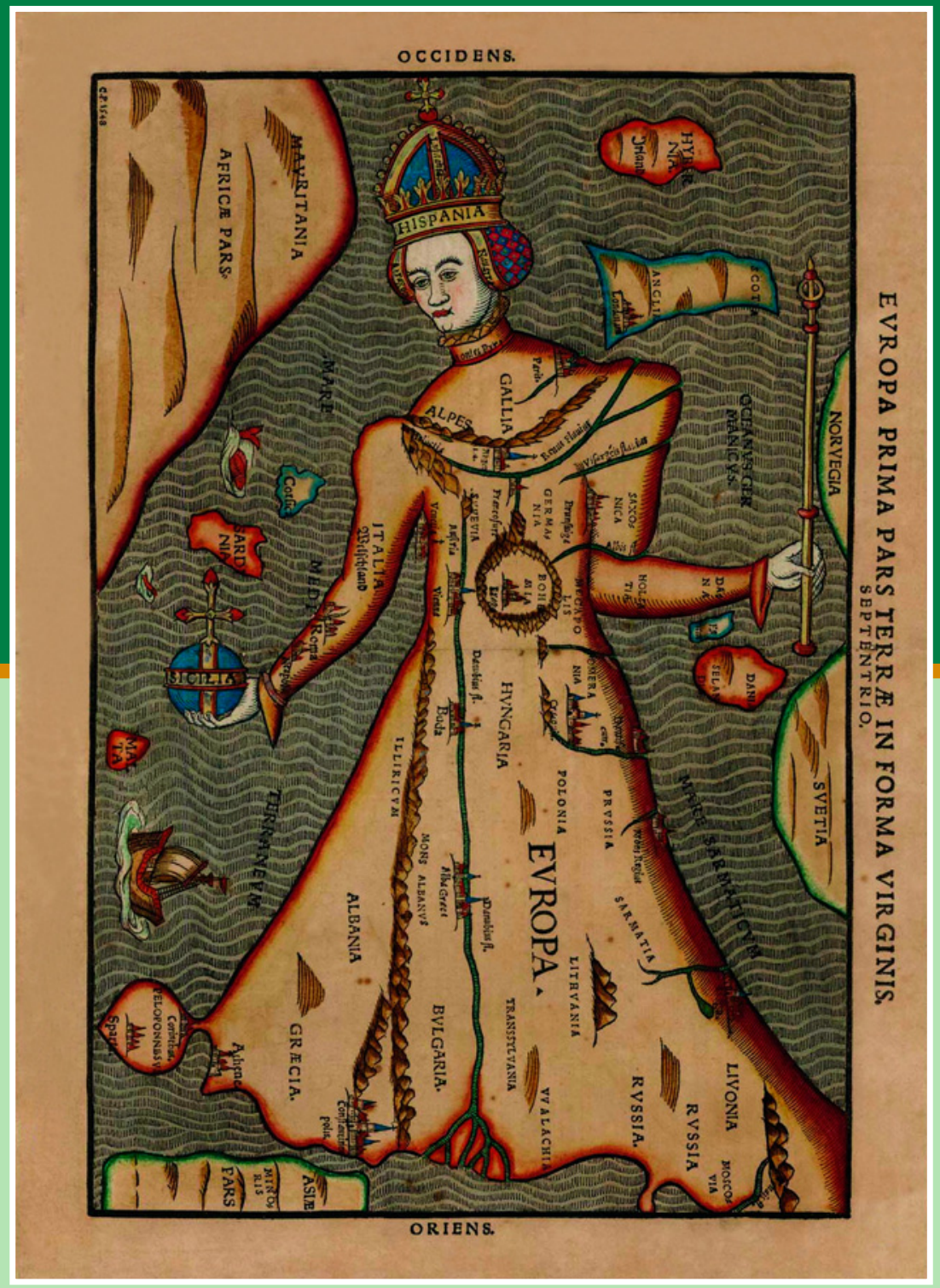

тели этому противоречить, или потому, что некоторые из них рассчитывали на то, чтобы поставить на какое-нибудь бедствие, и пришло кулучшению изавершению [это дело после прибытия] в Бенавенте, и стало так, что королева донья Хуана не знала и не утверждала дела правления, кроме одного только короля, а так как королевства принадлежали королеве и были ее наследственным владением, а не владением короля Филиппа, и прежде стало так, что в томалое время, которое прожил король Филипп, оттуда последовало для королевы немалое волнение и неприятность: и король дон Филипп обеспечил то, чтобы королева никаким образом не видела своего отиан.

Встреча отца и дочери, открывавшая перспективу для соглашения и документы] подписывала вместе с королем, как прежде блаженной памяти королева донья Изабелла с королем Фердинандом, ее отцом. Король Филипп и члены его совета и те, которые слишком продвинулись $\kappa$ тому, чтобы получить это, казалось, что они сошлись в этом совете для того, чтобы королева не подписывала [документы], либо, видя это мнение короля о том, что у нее должны были отнять, не захо- 


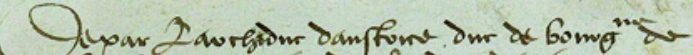

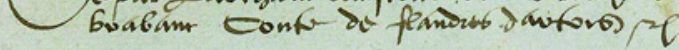

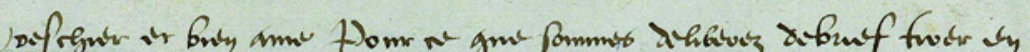

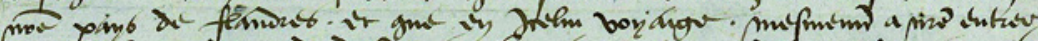

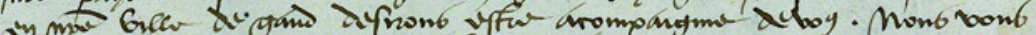

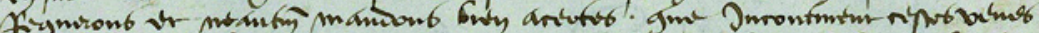

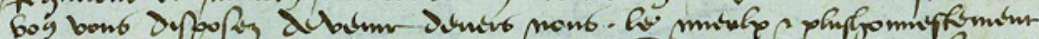

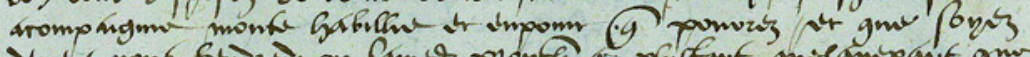

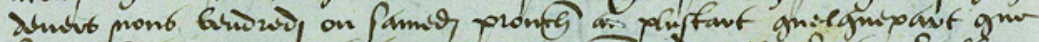

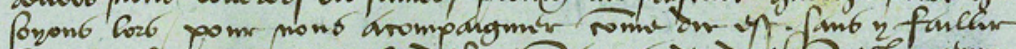

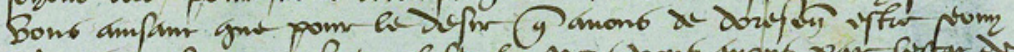

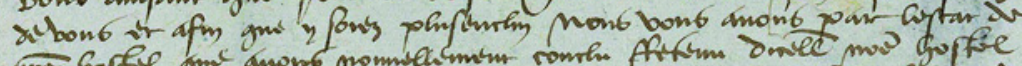

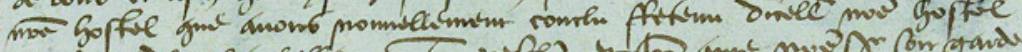

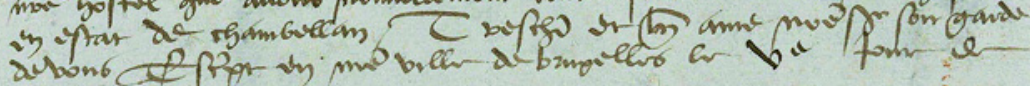
mawt@omoledy
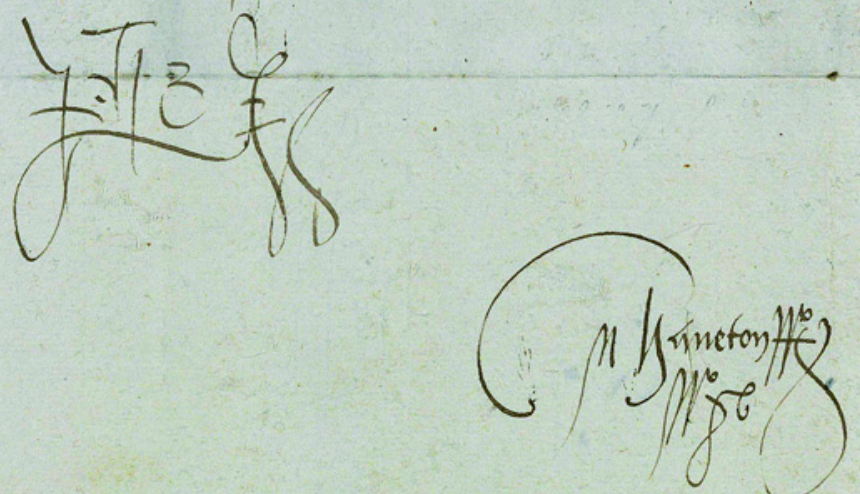

Собственноручное письмо Филиппа I графу графу де Лаллену.

Брюссель, 5 марта 1496 г.

\section{Внизу:}

Сражение Непобедимой испанской армады с английскими кораблями. Неизвестный художник английской школы XVI в.

Непобедимая армада - крупный военный флот, собранный Испанией в 15861588 годах для вторжения в Англию во время англо-испанской войны. В его состав входили около 130 судов, 2430 орудий, 30500 человек, из них 18973 солдата, 8050 матросов, 2088 рабов-гребцов, 1389 офицеров, дворян, священников и врачей. Армада также включала 4 неаполитанских галеаса, 4 португальских галеры, множество легких судов для разведки и посыльной службы и судов с припасами. Запасы продовольствия включали в себя миллионы галет, 600000 фунтов соленой рыбы и солонины, 400000 фунтов риса, 300 оОо фунтов сыра, 40000 галлонов оливкового масла, 14000 бочек вина, 6 ооо мешков бобов.

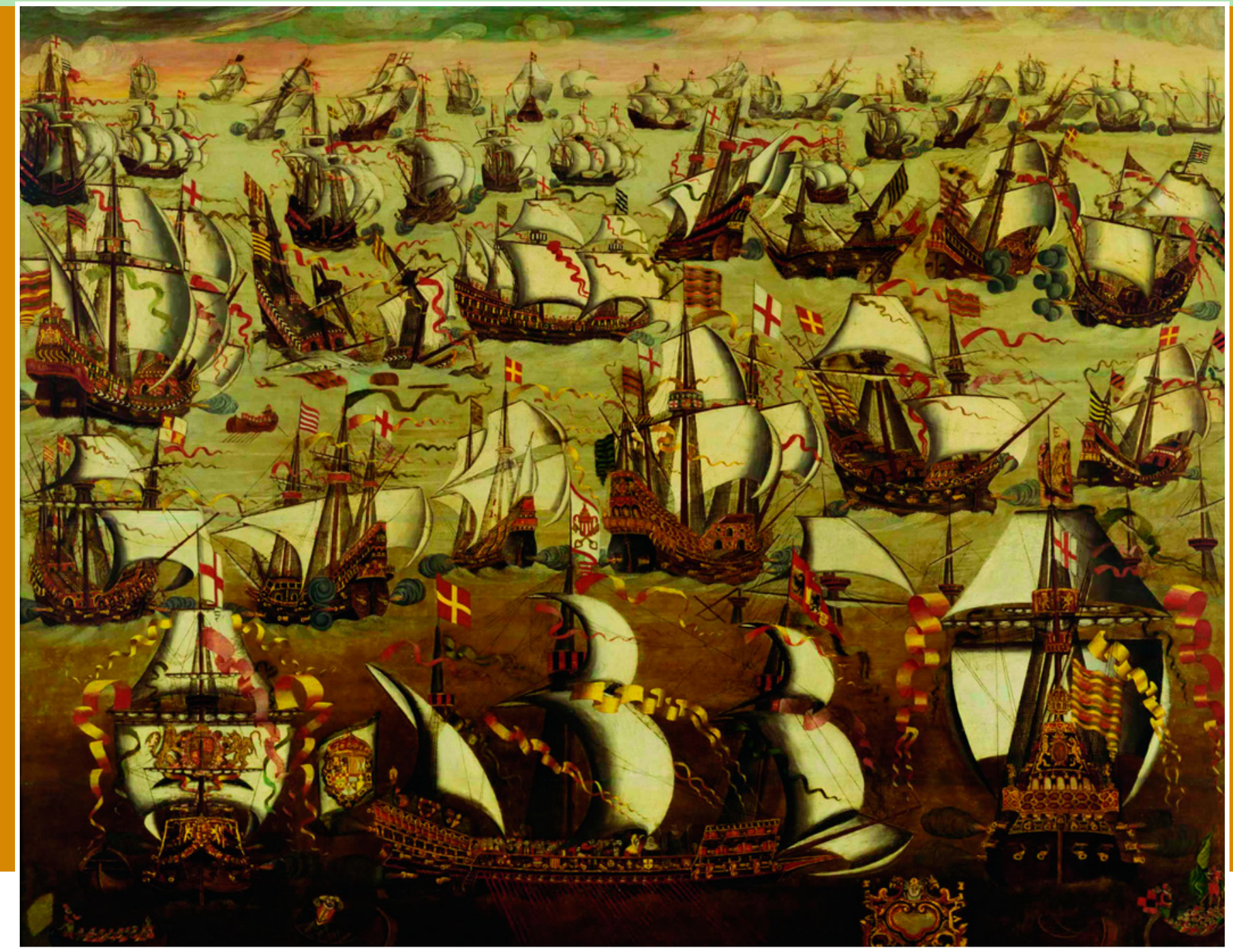


Портрет Филиппа I Кастильского. Художник Нидерландской школы. 1501 г. Музей Лувр, Париж. между ними, могла оказаться фатальной для политических амбиций Филиппа, целью которого являлось установление в Кастилии единовластия. Об этом говорит, в частности, Лоренсо Падилья, передавая разговор короля со своим посланником в Нидерландах Хуаном де ла Вега, сеньором Бельмонте, перешедшим на сторону Филиппа и ставшим первым испанцем, принятым в бургундский орден рыцарей Золотого Руна. По сообщению Падильи, когда король Фердинанд спросил у посланника, как они могли бы найти общий язык с зятем, чтобы можно было ввести его в управление королевствами, тот ответил, что Филипп «желал иметь его в качестве отиа $u$ господина, и не выходить из послушания, но, как хорочо известно, Его Высочеству, одно королевство не может выдержать того, чтобы в нем управляли два главы, и что во всем остальном он будет ему послушен как господину и отиу, и придет иеловать его руку туда, куда Его Высочество прикажет». Занять столь жестко сформулированную позицию стало возможным благодаря тому, что ведущие представители кастильской знати поддерживали Филиппа.

Встреча соперников у Пуэбла де Санабриа, которая иначе называется встречей на поле Ремесаль (20 июня), была весьма напряженной, о чем свидетельствуют рассказы современников, сообщающих, что Филипп и его окружение явились на переговоры вооруженными до зубов. Пьетро Мартир д' Англериа (1457-1526 гг.), известный гуманист и политический деятель, позднее вспоминал: «перед глазами тестя Филиппу предшествовали в прекрасном виде около тысячи вооруженных фламандцев, которые окружили Ферди нанда так, как будто хотели схватить его и сделать пленником.

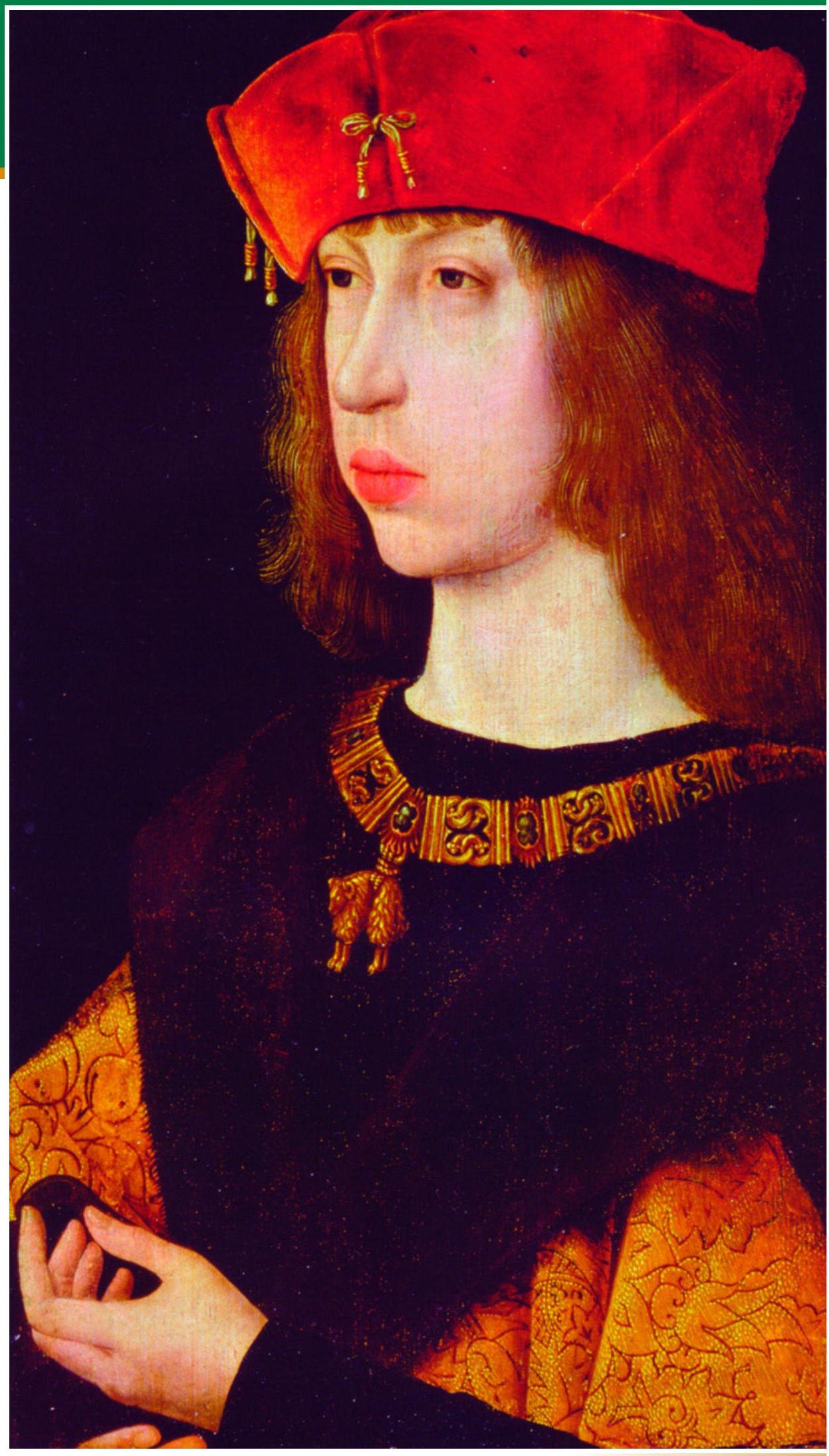

Наконец, появился Филипп. Зять и тесть начали двигаться, чтобы выйти навстречу друг другу, первый без какого-либо оружия, второй полностью вооруженный. Издали казалось, что зять говорит тестю раздраженным и враждебным тоном. Такя заключил поманере жестикулирования Филиппа».

Более сдержанно описал ситуацию Бернальдес, за словами которого, тем не менее, можно уловить остроту 


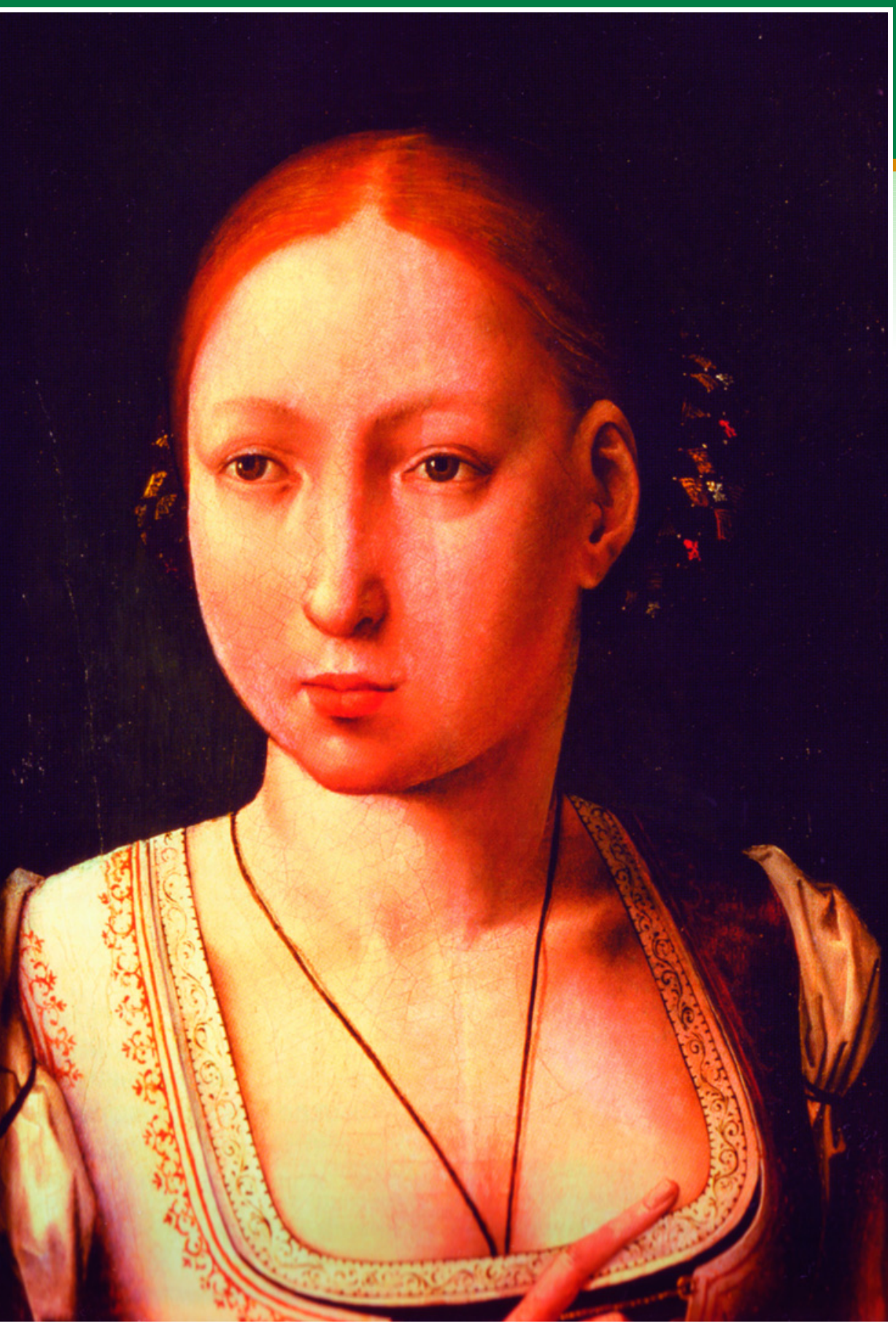

момента: «Король дон Фердинанд отправился из Торо и прибыл в Бенавенте, и увиделся и обнялся скоролем доном Филиппом, и простился с ним и рыцарями Кастилии, которые там находились, и обнял гериога Нахеры, графа Бенавенте и других; на промание, когда попрощался король дон Филипп, некоторые из них под свочми кирасами были вооружены, и король осуждающе сказал герцогу Нахеры: «Господь дарует вам милость, гериог, но вы сделались таким плотным", и также сказал другому, графу Бенавен-
Портрет Хуаны Безумной.

Худ. Хуан де Фландес. 1496-1500 гг.

Музей истории искусств, Вена.

наедине. И после попрощ,ались, и все гранды, которые сопровождали [короля Филиппа], проявили почтение к королю Фердинанду, который, чувствуя, что многие из них приили вооруженными, сказал Гарсиласо де ла Веге, главному командору Леона, что за короткое время он слишком располнел, и тот, извиняясьза себя, ответил королю, что [это] не было для какой-то одной стороны, но для того, чтобы сохранить [в безопасности] свою персону».

Иначе выглядела встреча в Ренедо (5 июля), которая прошла «с большой радостью и демонстрачией большой любви, хотя и с весыма неравным количеством спутников, так как уже тогда с королем Фердинандом остались только герцог Альба, дон Бернардино Рохас, маркиз де Дениа, и малое количество сеньоров. И после объявления и веселой встречи, которую один устроил другому, они одни вошли в местную церковь и находились в ней почти два часа в тайных переговорах, ине известно, что происходило, хотя предполагают, что это были советы, которые благоразумный и старый король дон Фердинанд давал своему зятю королю о той манере, какой должно держаться в управлении этими королевствами, сообщив ему о свойствах и состояниях их грандов и рыцарей; по их завершении они вышли и с любовью распрошались и больше не виделись» - сообщал Педро Мехиа.

Несколько деталей к этому рассказу позднее добавил арагонский хронист Херонимо Сурита (15121580 гг.), упомянувший о присутствии на переговорах третьего лица, архиепископа Толедо и примаса Испании Франсиско Хименеса де Сиснероса.

Подобный прорыв в отношениях стал возможен благодаря тому, что в конце июня 1506 года Филиппу и Фердинанду удалось найти компромиссное решение, которое известно как договор в Виллафафила. По 
Король Арагона Фердинанд II Католик. Художник Нидерландской школы. Начало XVI в. Музей Прадо, Мадрид. его условиям, Фердинанд должен был покинуть территорию Кастилии, однако остался великим магистром кастильских рыцарских орденов Алькантара, Калатрава и Сантьяго, сохранив половину доходов от экономической деятельности в колониях Нового Света. Также ему поступали 10 млн. мараведи из доходов рыцарских орденов в Кастилии.

1 июля Фердинанд официально заявил об отказе от своих прав на Кастилию в пользу дочери и зятя в Тордесильясском манифесте. 12 июля кастильские кортесы, собравшиеся в Вальядолиде, принесли присягу на верность Филиппу, его жене и их сыну Карлу. Однако единоличное правление, к которому так стремился Филипп, оказалось недолгим - после договора в Виллафафила он прожил менее трех месяцев.

Находясь в Бургосе, король 19 сентября посетил городскую крепость, комендантом которой был назначен сеньор Бельмонте, где пообедал и поиграл в мяч, после чего почувствовал себя плохо. У Филлипа началась лихорадка, и 25 сентября он скончался при не вполне ясных обстоятельствах. Хотя, утверждению Бернальдеса, король, наблюдаемый фламандскими докторами, умер от чумы, эпидемия которой началась в это время, приближенный Филиппа Антуан де Лэлэн писал, что «некоторые имели большие подозрения относительно того, что добрый король скончался от яда».

Смерть мужа усугубила психическое состояние Хуаны, которая была беременна. Уезжая из Бургоса, она забрала с собой его забальзамированное тело, извлеченное из крипты монастыря Мирафлорес, чтобы доставить его в Гранаду, однако, до пред-
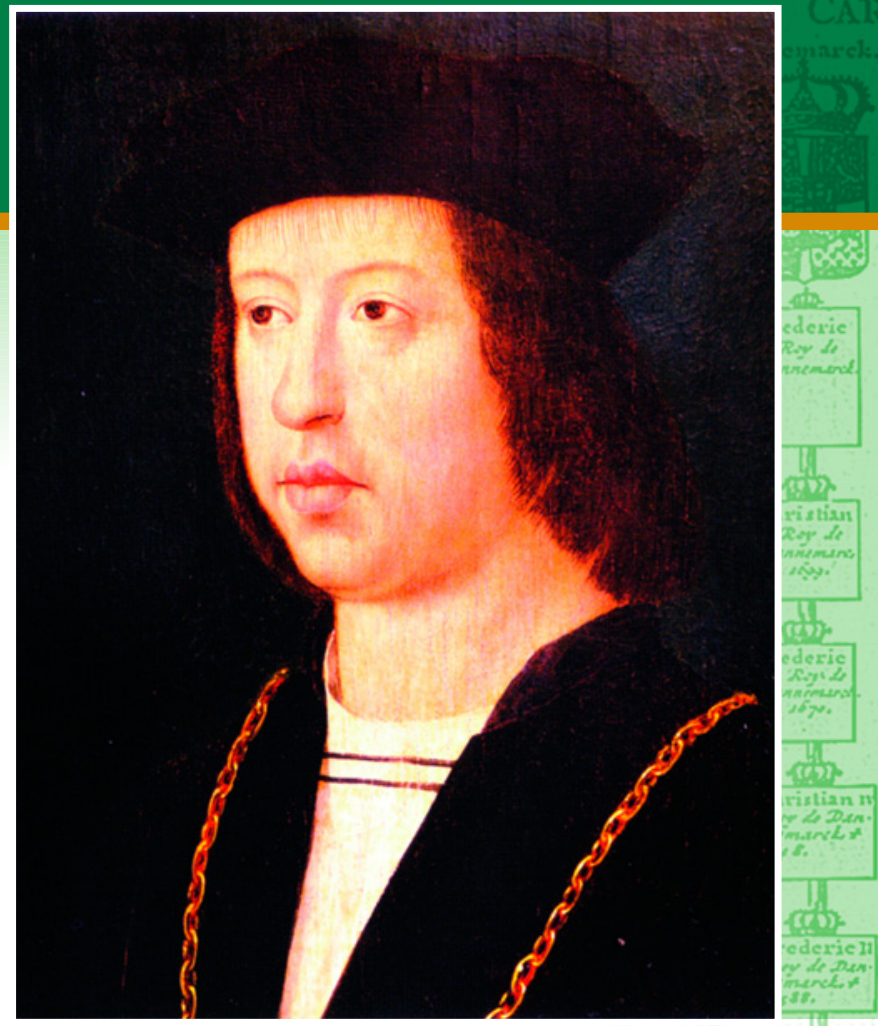

полагаемого «места назначения» траурный кортеж так и не добрался. Королева перевозила останки мужа из одного места в другое по ночам, не давая приблизиться к ним ни одной женщине, и время от времени приказывала вскрывать гроб. Пьетро Мартир д' Англериа утверждал, что королеву «сжигали те же самые приступы ревности, которые мучили ее, когда был жив ее муж». Алонсо де Санта-Крус позднее осторожно писал о том, что после смерти короля Филиппа Хуана "стала вести очень печальную жизнь, довольствуясь одиночеством в мрачных местах, всегда очень задумчивая, не говорящая ни слова; так как ей не нравилось какое-либо общество, не имелось возможности завериить утверждение документов с нею или сделать какую-либо другую вещь».

\section{1 июля Фердинанд официально заявил об отказе} от своих прав на Кастилию в пользу дочери и зятя в Тордесильясском манифесте. 12 июля кастильские кортесы, собравшиеся в Вальядолиде, принесли присягу на верность Филиппу, его жене и их сыну Карлу. Однако единоличное правление, к которому так стремился Филипп, оказалось недолгим - после договора в Виллафафила он прожил менее трех месяцев.

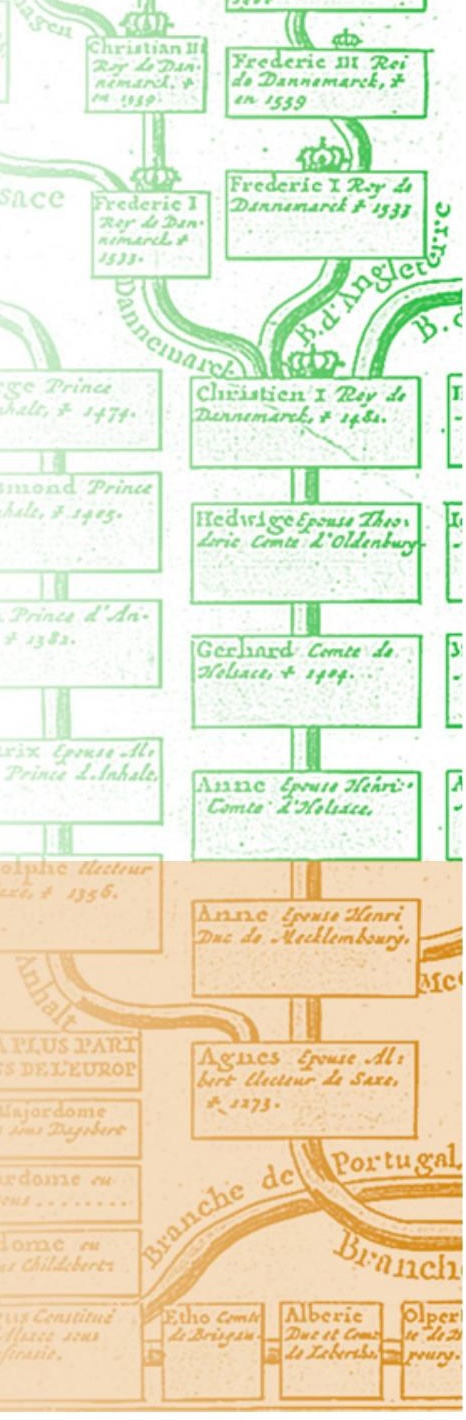

HISTORY illusluated 


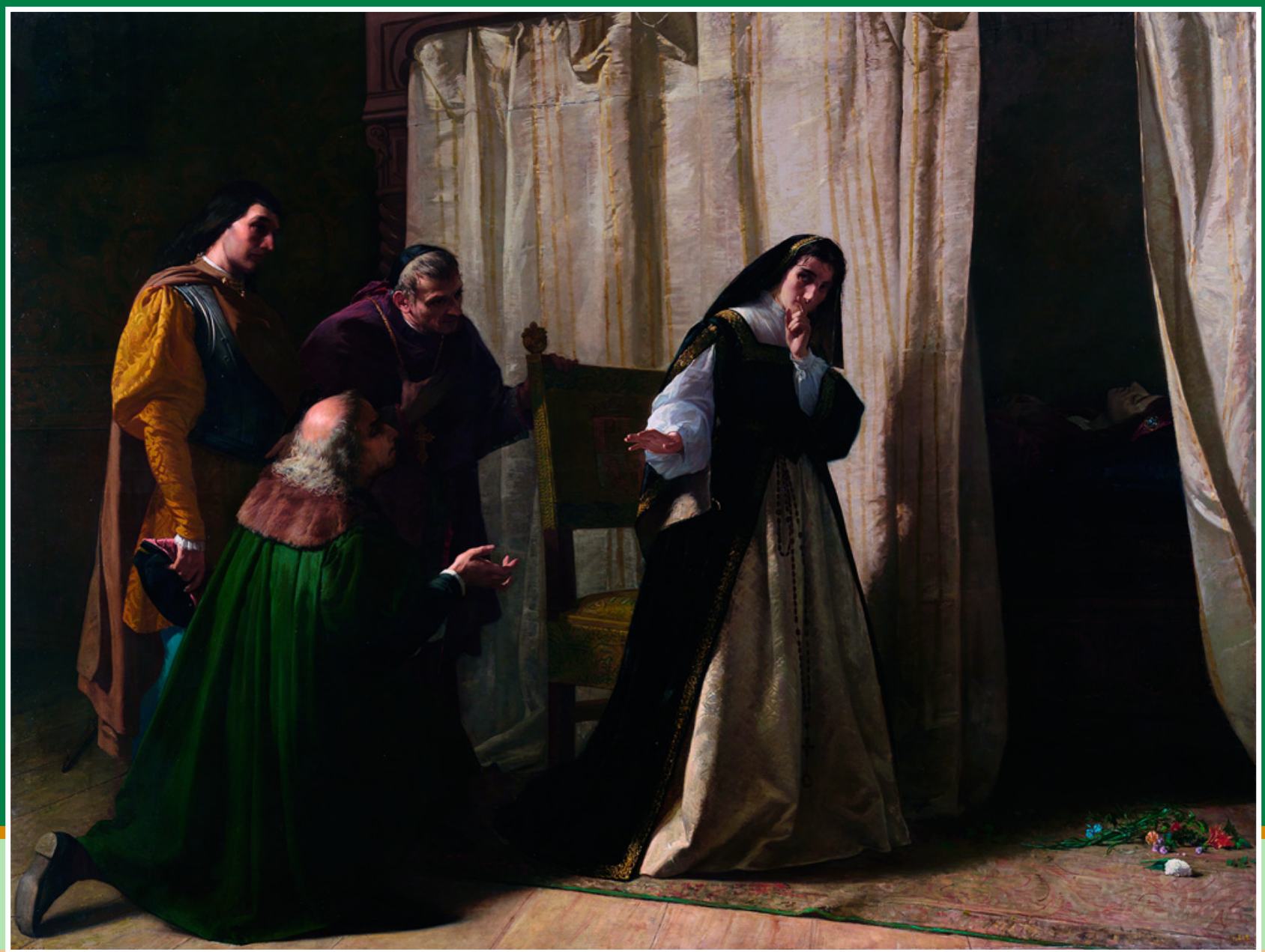

Деменция Хуаны Безумной Худ. Лоренцо Вальес. 1866 г. Музей Прадо, Мадрид.

В королевстве образовался вакуум власти, поскольку Хуана отказалась контактировать с членами королевского совета и отвергла предложение о созыве кортесов. На повестку дня был поставлен вопрос об установлении регентства, приведший кастильскую знать к расколу. Одна ее часть, основываясь на завещании Изабеллы, настаивала на возвращении к власти Фердинанда: другая возражала против этого, желая сохранить ситуацию, сложившуюся после подписания договора в Виллафафила, который устранил Фердинанда из политической жизни Кастилии. Противники арагонского короля - герцог Нахера, маркиз Виллена, граф Бенавенте, сеньор

На собрании сословных представителей Кастилии в Бургосе регентство было официально передано королю Фердинанду до совершеннолетия его внука Карла. Герцог Нахера, отказавшийся там присутствовать, не признал данного решения, и против мятежника были приняты меры, в результате чего его замки перешли под контроль более лояльного герцога Альбы.

Бельмонте и некоторые другие, ранее группировавшиеся вокруг Филиппа, теперь пытались противопоставить правам Фердинанда права его малолетних сыновей, рассчитывая на поддержку Максимилиана I. C ними была солидарна группа феодалов из Андалусии маркиз Плиего, графы Уренья, Кабра и другие, но инициативу удалось перехватить «временному правительству», которое возглавил Франсиско Хименес де Сиснерос, призвавший в Кастилию Фердинанда.

Известие о кончине зятя застало Фердинанда на пути к Генуе, но он отказался вернуться в Кастилию и продолжал путь на юг, где более полугода занимался делами Неаполитанского королевства, которое 


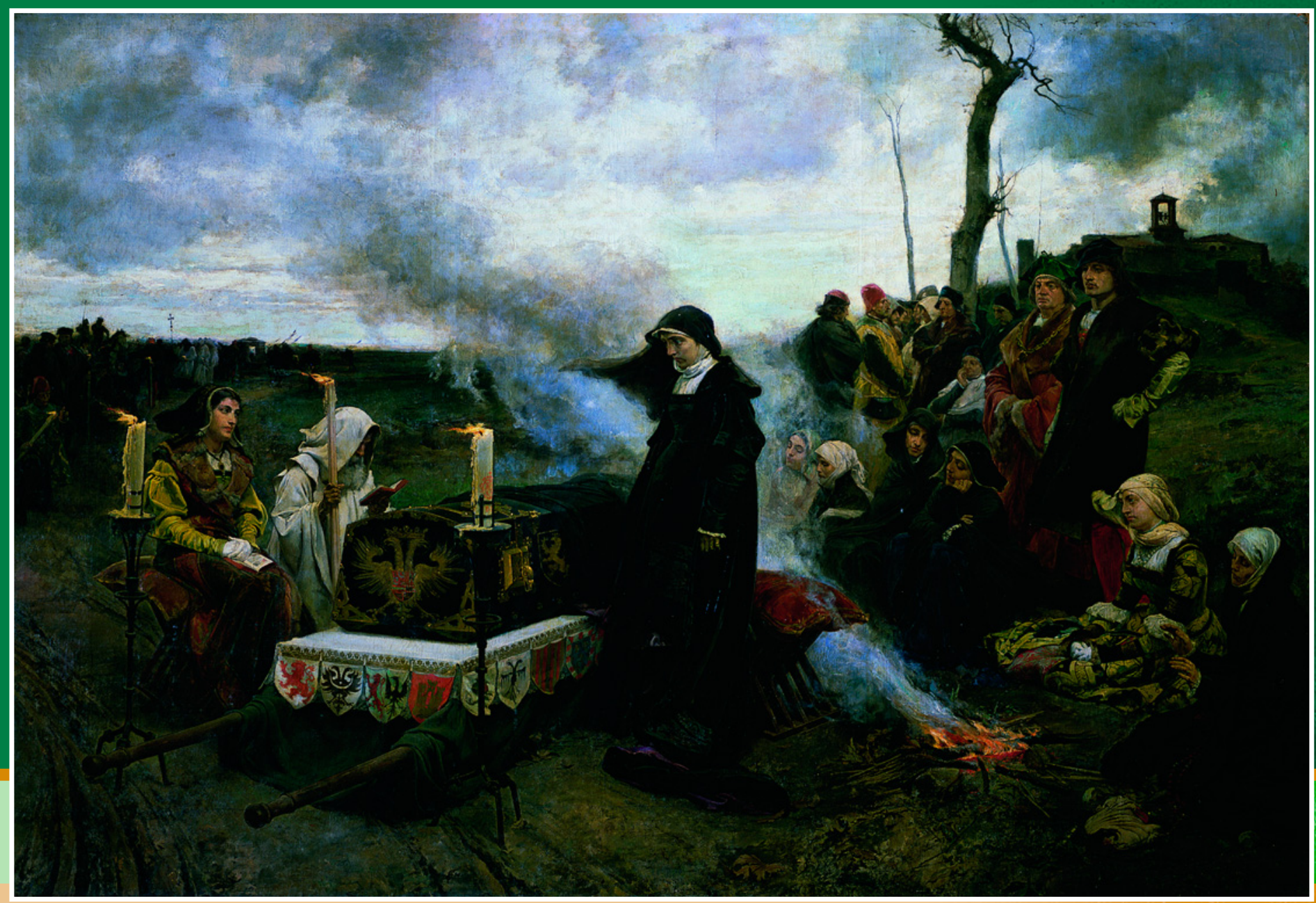

Хуана Безумная над гробом мужа Филиппа Красивого. Худ. Франсиско Прадилья-и-Ортис. 1878 г. Музей Прадо, Мадрид, Испания.

перешло под полный его контроль после заключения мирного договора с Францией в 1504 году.

Вернувшись на Пиренейский полуостров летом 1507 года, король Арагона занялся упрочением своей власти в Кастилии и принял меры к нейтрализации оппозиционных аристократов. Как отмечает Лоренсо Падилья, «в ту пору крепость Бургос, которую держал дон Хуан Мануэль, не хотела признавать короля дона Фердинанда и дон Хуан находился с герцогом Нахерой, который держался того же мнения». Крепость была осаждена и вынуждена капитулировать, а сам сеньор Бельмонте «в одежде монаха отправился назад во Фландрию, потому что король поставил многочисленную охрану во всех населенных пунктах $u$ [на всех] дорогах, чтобы схватили его, и написал королю Франиии, чтобы задержали его, если он пойдет через его королев- cmво». Через территорию Прованса и Савойи опальный аристократ все же добрался до Фландрии, где был арестован значительно позже, в 1513 году, по приказу эрцгерцогини Маргариты, которая после смерти своего брата Филиппа исполняла обязанности регентши в Нидерландах.

На собрании сословных представителей Кастилии в Бургосе регентство было официально передано королю Фердинанду до совершеннолетия его внука Карла. Герцог Нахера, отказавшийся там присутствовать, не признал данного решения, и против мятежника были приняты меры, в результате чего его замки перешли под контроль более лояльного герцога Альбы.

Фердинанд распорядился похоронить тело короля Филиппа, а дочь, вошедшую в анналы истории как Juana La Loca или Хуана Безумная, приказал поместить под надзор в королевской резиденции в Тордесильясе.

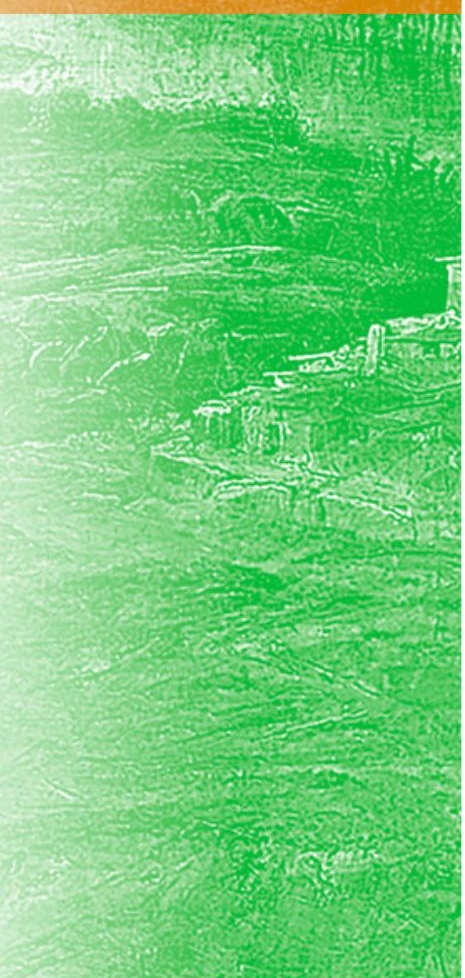

